\title{
Another, new dermatosis in the spectrum of pigmented purpuric dermatoses or atypical variant of lichen aureus?
}

\author{
Kolejna, nowa dermatoza z grupy barwnikowych dermatoz plamiczych \\ czy nietypowa postać liszaja złocistego?
}

\author{
Martyna Sławińska', Monika Sikorska', Małgorzata Sokołowska-Wojdyło', Roman J. Nowicki', Wojciech Biernat², \\ Michał Sobjanek'
}

\author{
'Department of Dermatology, Venereology and Allergology, Medical University of Gdańsk, Poland \\ 2Department of Pathomorphology, Medical University of Gdańsk, Poland \\ 'Katedra i Klinika Dermatologii, Wenerologii i Alergologii Gdańskiego Uniwersytetu Medycznego, Polska \\ ${ }^{2}$ Katedra i Zakład Patomorfologii Gdańskiego Uniwersytetu Medycznego, Polska
}

Pigmented purpuric dermatoses (PPD) are a group of dermatoses with common histopathological findings and diverse clinical presentation. The traditional classification includes six subtypes: lichen aureus, itching purpura, purpura annularis telangiectodes (Majocchi purpura), pigmented purpuric lichenoid dermatitis of Gougerot-Blum, progressive PPD (Schamberg purpura), and eczematid-like purpura of Doucas and Kapetanakis [1]. Nevertheless, there are some descriptions of cases that share the histopathological features of PPD, but the clinical presentation is not typical for any of the above-mentioned entities [2-4]. We describe another atypical case, which is clinically and dermatoscopically similar to the one presented by Zalaudek et al. [4].

A 13-year-old, otherwise healthy, girl presented with a red-brownish plaque on the lower leg near the lateral malleolus (fig. $1 \mathrm{~A}$ ). The asymptomatic, slowly growing lesion was present for 12 months. The patient denied taking any medications and had no history of trauma of the affected site. The family history was unremarkable. On clinical examination the plaque consisted of 1-2 mm confluent papules covered with a whitish scale. Dermoscopically, the lesion presented a pattern of red and brown irregularly distributed globules and dots and a light-brown reticular network at the periphery interrupted by a white scale in a linear distribution (figs. 1 B-D). The histopathological examination of the lesion revealed psoriasiform hyperplasia of the epidermis with discrete parakeratotic foci and dense, band-like dermal infiltrate composed of small
Barwnikowe dermatozy plamicze (pigmented purpuric dermatoses - PPD) są grupą chorób skóry o zbliżonym obrazie histopatologicznym i różnorodnym obrazie klinicznym. Według tradycyjnej klasyfikacji do spektrum PPD zalicza się: liszaja złocistego, plamicę świądową, plamicę obrączkową teleangiektyczną (chorobę Majocchiego), liszajowate plamicze zapalenie skóry (zespół Gougerota-Bluma), postępującą plamicę barwnikową (chorobę Schamberga) i plamicę wypryskopodobną (chorobę Doucasa-Kapetanakisa) [1]. W piśmiennictwie dostępne są jednak opisy przypadków, w których obraz histologiczny jest charakterystyczny dla PPD, a objawy klinicznie nie odpowiadają żadnej z wymienionych chorób [2-4]. Przedstawiamy kolejny, nietypowy przypadek, który jest zbliżony pod względem obrazu klinicznego i demoskopowego do przypadku opisanego w pracy Zalaudek i wsp. [4].

Trzynastoletnią, ogólnie zdrową pacjentkę konsultowano z powodu czerwono-brunatnej, asymptomatycznej zmiany skórnej umiejscowionej w okolicy lewej bocznej kostki (ryc. 1 A). Zmiana pojawiła się 12 miesięcy wcześniej i powoli się powiększała. Wywiad w kierunku przyjmowanych leków oraz ewentualnego urazu był ujemny, podobnie jak wywiad rodzinny w kierunku chorób skóry. W badaniu przedmiotowym ujawniono obecność czerwono-brunatnej blaszki utworzonej z licznych 1-2-milimetrowych grudek, pokrytej niewielką ilością białej łuski. W dermoskopii stwierdzono obecność czerwonych i brązowych kropek oraz grudek o nieregularnym rozmieszczeniu, jasnobrązowej siatki barwnikowej oraz białej łuski, miejscami o układzie linijnym (ryc. 1 B-D). W badaniu histopatologicznym wykazano 


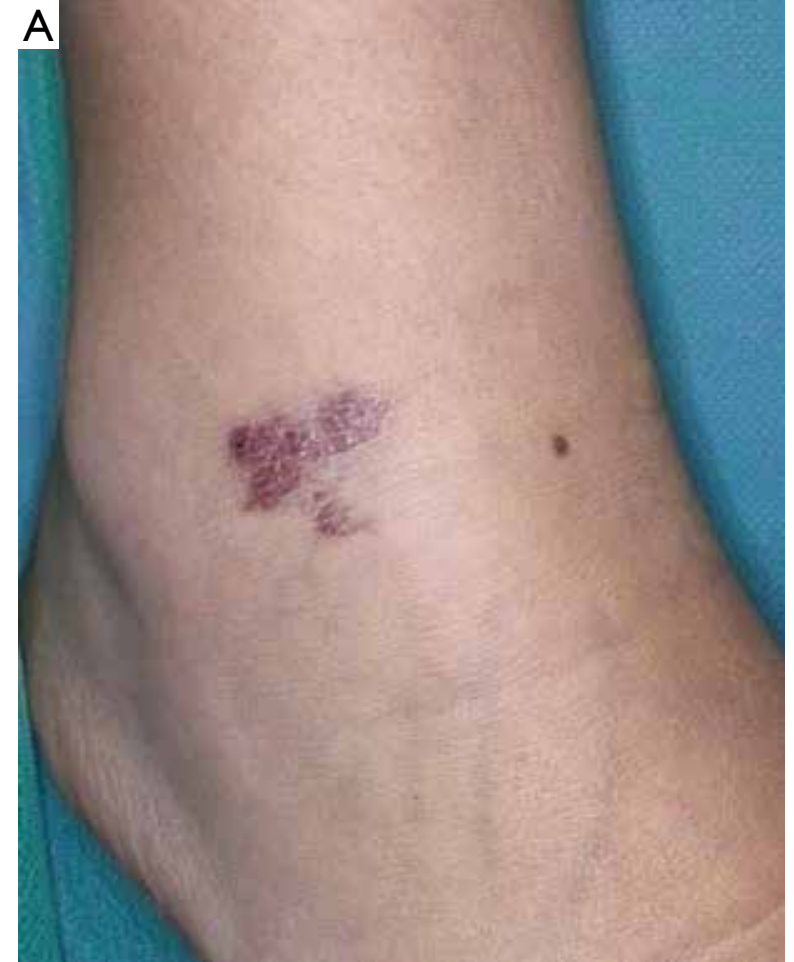

Figure I. A - Clinical presentation: red-brownish plaque on the lower leg near the lateral malleolus. B-D - Dermoscopy shows the pattern of red and brown irregularly distributed globules and dots, light-brown subtle reticular network at the periphery as well as the white scale in a linear distribution

Rycina I. A - Obraz kliniczny: czenwono-brqzowa blaszka umiejscowiona w okolicy kostki bocznej. B-D - W obrazie dermoskopowym uwidoczniono nieregularnie rozmieszczone czerwono-brązowe globule i kropki, jasnobrq̨zowq, subtelnq siatkę barwnikowq w obwodowych częściach zmiany oraz białq łuskę, o linijnym układzie

lymphocytes intermingled with scattered siderophages and extravasated erythrocytes. Epidermal lymphocyte exocytosis was not present. CD4+ lymphocytes prevailed slightly over CD8+ cells with a noticeable decrease of CD7 expression. The whole appearance confirmed the diagnosis of PPD (fig. 2). Clinically, it did not match any of the above-mentioned subtypes. Another biopsy performed after 6 months was similar to the former one.

Pigmented purpuric dermatoses is a general term relating to a group of chronic, uncommon dermatoses characterized by similar histopathological features including perivascular lymphocytic infiltration, erythrocyte extravasation and hemosiderin deposition. Apart from the six clinical categories of PPD, some atypical presentations of PPD have been described. There are limited data concerning PPD in the pediatric population. It is known that all clinical variants may occur in children, while Schamberg purpura is the most common type [5].

Lichen aureus (LA) classically presents as an asymptomatic, solitary, unilateral gold-brown
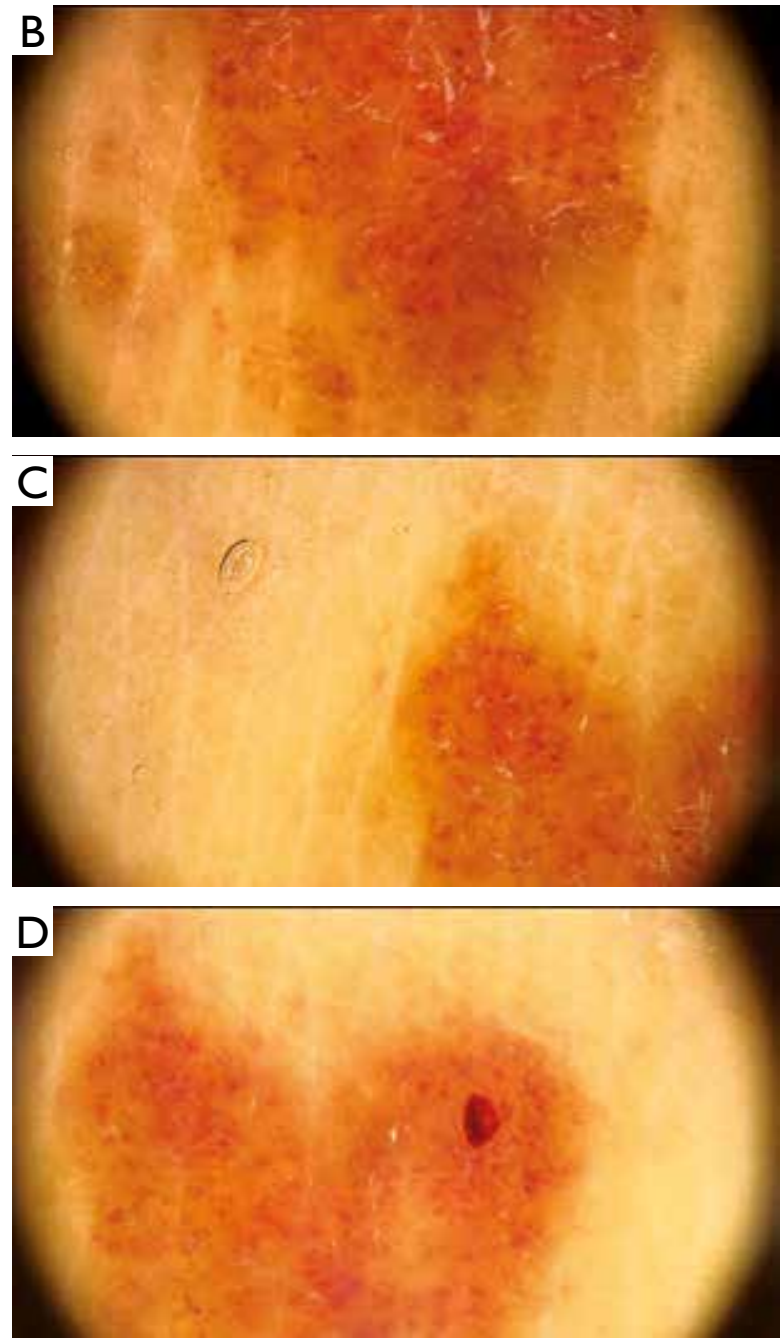

łuszczycopodobną hiperplazję naskórka z zaznaczonymi ogniskami parakeratozy oraz widocznym w obrębie skóry właściwej pasmowatym naciekiem utworzonym przez niewielkie limfocyty z towarzyszącymi rozproszonymi syderofagami i wynaczynionymi erytrocytami. Nie stwierdzono egzocytozy limfocytów do naskórka. Stwierdzono lekką przewagę limfocytów CD4+ nad CD8+ z wyraźnym zmniejszeniem ekspresji CD7. Całość obrazu klinicznego przemawiała za rozpoznaniem PPD, jednak obraz kliniczny nie był w pełni spójny z żadnym z powyżej wymienionych schorzeń. Obraz histopatologiczny kolejnego wycinka skórnego pobranego po 6 miesiącach był podobny.

Barwnikowe dermatozy plamicze są grupą przewlekłych, rzadko występujących chorób skóry, które cechuje zbliżony obraz histopatologiczny, obejmujący okołonaczyniowe nacieki limfocytarne, wynaczynienia erytrocytów i obecność złogów hemosyderyny. Niezależnie od sześciu kategorii klinicznych PPD opisywano również przypadki o nietypowym obrazie. Dane dotyczące PPD u dzieci są ograniczone. W tej grupie wiekowej mogą występować wszystkie warianty kliniczne, 

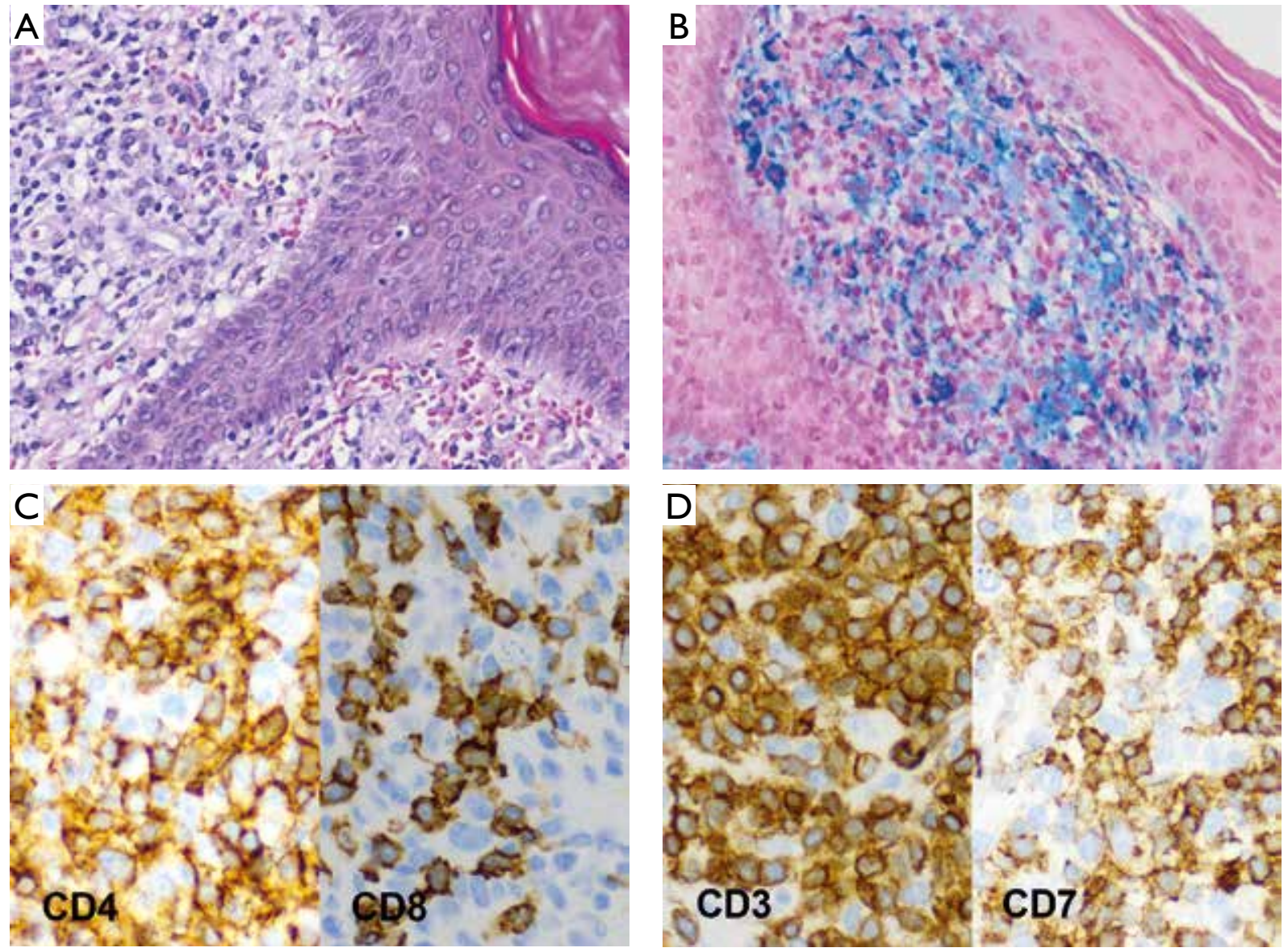

Figure 2. Histopathological presentation: the dermal infiltrate composed of lymphocytes shows focal erythrocyte extravasation (A) and iron accumulation (B). The prevalence of CD4+ over CD8+ lymphocytes with slight decrease in CD7 expression is shown in the lower row of illustrations (C, D)

Rycina 2. Obraz histopatologiczny: w obrębie skóry właściwej widoczny jest naciek limfocytarny, miejscami z obecnością wynaczynionych erytrocytów (A) oraz złogów żelaza (B). W obrębie nacieku przeważają limfocyty CD4+ > CD8 + z niewielkim zmniejszeniem ekspresji CD7 (C, D)

lichenoid patch. The most frequent locations are the lower extremities. The course of the disease is usually stable, although spontaneous resolutions were also noted - more commonly in pediatric patients. Clinically, the present case met most clinical diagnostic features of LA, but the white scale observed on the surface of the lesion and lack of gold color made the clinical diagnosis less obvious.

The initial diagnosis of PPD is based on clinical examination which may be supported by dermoscopy. The most common, recently described, dermoscopic findings are coppery-red pigmentation in the background, red globules, red dots, brown dots and a reticular network [6]. We observed all these features in the present case; additionally we observed white lines corresponding to the superficial scale. Regardless of that, current evidence shows that in the case of PPD, especially with atypical clinical presentation, histopathological evaluation should always be performed in order to exclude mycosis fungoides mimicking PPD $[4,7,8]$. Additionally, cases of PPD that przy czym najczęstszym jest choroba Schamberga [5]. Klasyczny obraz liszaja złocistego (lichen aureus - LA) to pojedyncza, asymptomatyczna, złocistobrązowa plama, często z drobnymi grudkami liszajowatymi na obrzeżu, umiejscowiona najczęściej w obrębie kończyn dolnych. Przebieg choroby jest zazwyczaj stabilny, choć obserwowano również przypadki samoistnego ustępowania zmian (częściej u pacjentów pediatrycznych). Z klinicznego punktu widzenia przedstawiony przypadek spełnia część kryteriów diagnostycznych LA, jednak ze względu na białą łuskę na powierzchni zmiany oraz brak złocistego zabarwienia rozpoznanie kliniczne nie jest oczywiste.

Wstępne rozpoznanie PPD opiera się na badaniu klinicznym. Rola dermoskopii jest pomocnicza. W obrazie dermoskopowym najczęściej stwierdza się czerwone grudki i kropki, brązowe kropki i siatkę barwnikową na podłożu obszarów bezstrukturalnych w kolorze miedzianobrązowym [6]. Wszystkie wymienione cechy występowały w opisywanym przypadku. Ponadto obserwowano białe łuski o linijnym układzie. Dostępne dane 
progressed to mycosis fungoides (MF) have been described. The clinical features that should raise the suspicion of MF are extensive involvement and persistent pruritus. Irrespectively, an assessment of T-cell clonality should be performed as it is perceived as lymphoid dyscrasia [9]. Cases with the presence of a monoclonal T-cell population are more likely to progress to malignancy and require a further follow-up [8].

In summary, our case is another atypical presentation in the spectrum of PPD. Dermoscopy seems to be a useful diagnostic tool in making the initial diagnosis, but further studies are warranted to establish the specificity of the observed pattern.

\section{CONFLICT OF INTEREST}

The authors declare no conflict of interest. wskazują, że w każdym przypadku PPD, zwłaszcza o nietypowym obrazie klinicznym, należy przeprowadzić badanie histopatologiczne w celu wykluczenia ziarniniaka grzybiastego (mycosis fungoides - MF), naśladującego PPD $[4,7,8]$. W piśmiennictwie opisywano ponadto przypadki progresji PPD do MF. Wśród objawów klinicznych, które powinny wzbudzić podejrzenie MF, należy wymienić rozległość zmian i uporczywy świąd. Pomocna jest ocena klonalności limfocytów T ze względu na postulowane zaliczenie PPD do dyskrazji limfoidalnych [9]. W przypadkach, w których stwierdza się obecność populacji monoklonalnych limfocytów T, występuje zwiększone prawdopodobieństwo transformacji nowotworowej - wymagają one dalszej obserwacji [8].

Podsumowując - przedstawiono kolejny przypadek schorzenia ze spektrum PPD o nietypowym obrazie klinicznym. Dermoskopia wydaje się przydatnym narzędziem w diagnostyce PPD. Dalsze badania są niezbędne, aby ustalić czułość i swoistość diagnostyczną metody w tym zakresie.

\section{KONFLIKT INTERESÓW}

Autorzy deklarują brak konfliktu interesów.

\section{References}

\section{Piśmiennictwo}

1. Kim D.H., Seo S.H., Ahn H.H., Kye Y.C., Choi J.E.: Characteristics and clinical manifestations of pigmented purpuric dermatosis. Ann Dermatol 2015, 27, 404-410.

2. Mar A., Fergin P., Hogan P.: Unilateral pigmented purpuric eruption. Australas J Dermatol 1999, 40, 211-214.

3. Sardana K., Sarkar R., Sehgal V.N.: Pigmented purpuric dermatoses: an overview. Int J Dermatol 2004, 43, 482-488.

4. Zalaudek I., Ferrara G., Brongo S., Giorgio C.M., Argenziano G.: Atypical clinical presentation of pigmented purpuric dermatosis. J Dtsch Dermatol Ges 2006, 4, 138-140.

5. Coulombe J., Jean S.E., Hatami A., Powell J., Marcoux D., Kokta V.: Pigmented purpuric dermatosis: clinicopathologic characterization in a pediatric series. Pediatr Dermatol 2015, 32, 358-362.

6. Ozkaya D.B., Emiroglu N., Su O., Cengiz F.P., Bahali A. G., Yildiz P.: Dermatoscopic findings of pigmented purpuric dermatosis. An Bras Dermatol 2016, 91, 584-587.

7. Barnhill R.L., Braverman I.M.: Progression of pigmented purpura-like eruptions to mycosis fungoides: report of three cases. J Am Acad Dermatol 1988, 19, 25-31.

8. Riyaz N., Sasidharanpillai S., Abdul Latheef E.N., Davul H., Ashraf F.: Pigmented purpuric dermatosis or mycosis fungoides: a diagnostic dilemma. Indian Dermatol Online J 2016, 7, 183-185.

9. Magro C.M., Schaefer J.T., Crowson A.N., Li J., Morrison C.: Pigmented purpuric dermatosis: classification by phenotypic and molecular profiles. Am J Clin Pathol 2007, 128, 218-229.

Received: 8.08.2017

Accepted: 29.10.2017

Otrzymano: 8.08.2017 r.

Zaakceptowano: $29.10 .2017 \mathrm{r}$.

How to cite this article

Sławińska M., Sikorska M., Sokołowska-Wojdyło M., Nowicki R.J., Biernat W., Sobjanek M.: Another, new dermatosis in the spectrum of pigmented purpuric dermatoses or atypical variant of lichen aureus? Dermatol Rev/Przegl Dermatol 2017, 104, 672-675. DOI: https://doi.org/10.5114/dr.2017.71839. 